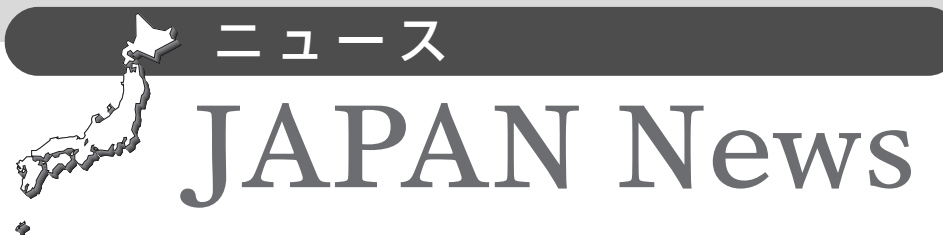

\title{
平成24(2012)年 7月九州北部豪雨に伴って阿蘇力ルデラ内の斜面で発生した地すべりや土石流の事例
}

Landslides and debris flows on the slopes at Aso Caldera induced by heavy rain event in northern Kyushu on July 2012

浅野志穂 Shiho ASANO / 森林総合研究所九州支所, 阿蘇地域の土砂災害調査グループ Kyushu Research Center, Forestry and Forest Products Research Institute, and Group of Field Survey of Sediment-Related Disasters in Aso Area

\section{1.はじめに}

梅雨前線の停滞に伴い，平成 24 年 6 月 下旬から 7 月中旬にかけて九州中部から 北部一帯において豪雨が繰り返し発生し, 各地で土砂災害が発生した。このうち阿 蘇地域では, 7 月 12 日夜半頃から朝にか けて断続的に豪雨が発生した。気象庁ア メダス観測データ（阿蘇乙姫）によると， 降雨継続時間が約 8 時間，その間の総雨 量が $491 \mathrm{~mm}$, 最大時間降雨量が $108 \mathrm{~mm}$ となる非常に強い雨であった。それ以前 までの降雨の影響等も重なり，この時は 阿蘇市，熊本市や竹田市等では，河川の 汇濫等の洪水被害が発生した。その一方 で，阿蘇カルデラ内の中央火口丘や外輪 山の内壁斜面では，多数の崩壊・地すべ りや土石流が発生し，多くの集落が被害 を受けた。阿蘇カルデラ内で発生した崩 壞地は，外輪山の北部〜東部地域の内壁 斜面や，東外輪山の根子岳や中央火口丘 の高岳の斜面に多く分布する傾向が見ら れた。これらは豪雨をもたらした雨雲の 分布に影響を受けたものと考えられる。 ここでは, 緊急的に行った現地調査で確 認できた範囲で，地すべりや土石流等の 事例を報告する。調査グループの構成員

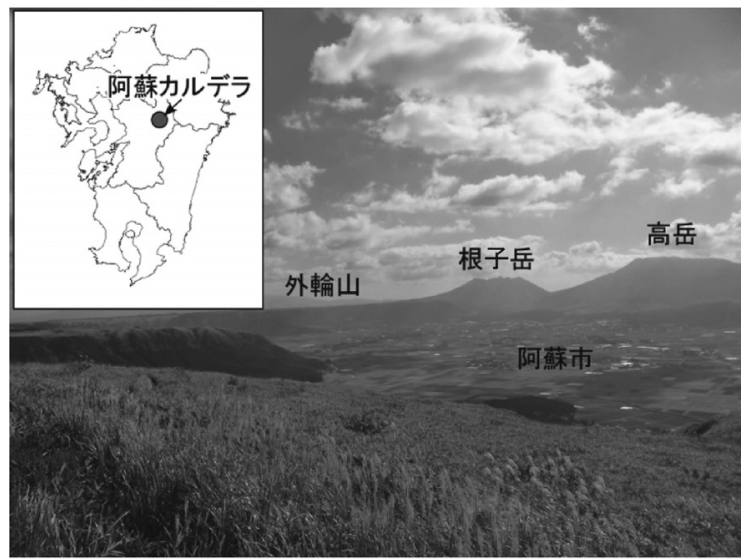

図－1＼cjkstart阿蘇カルデラの位置とカルデラ北東部分の遠景
を末尾の表に記す。

\section{2. 中央火口丘等の山麓草地斜面の表層 崩壊}

高岳や根子岳等の山麓付近には牧畜の ための草地が広く分布している。このう ち高岳や根子岳の北側山麓の草地斜面で は, 高い密度で表層崩壊が発生した（写 真 -1$)$ 。崩壊の深さは浅く, 土砂は板 状に崩落した。斜面勾配は40度前後の急 勾配となっている箇所も多い。崩壊地は 斜面の上部，中部，下部のそれぞれの場 所で発生しており, 崩壊土砂は表層の黒 色火山灰層が主体であった。同様の崩壊 は1990年や2001年にも発生しており（宮 縁ら；2004，大丸；2010)，黒色火山灰
層とその下の火山灰層の透水性の違いが 崩壊の発生に影響した可能性が指摘され ている（清水ら；1992）。斜面上部から 発生した崩壊土砂が発生位置より下部斜 面にある草本の上を滑り落ちたと思われ る痕跡も多く見られた (写真 -2$)$ 。

\section{3. 外輪山斜面上中部の崩壊や土石流}

阿蘇カルデラの外輪山の北側〜東側地 域の内壁斜面では, 崩壊や土石流が多数 発生した（写真－3）。特に手野地区か ら妻子ヶ鼻にかけての地域は崩壊や土石 流の発生密度が高い。外輪山の内壁斜面 の勾配は急であり, 崩壊は斜面のさまざ まな高さで発生しているが, 斜面上部で 崩壊が発生し，崩落土砂が土石流化して

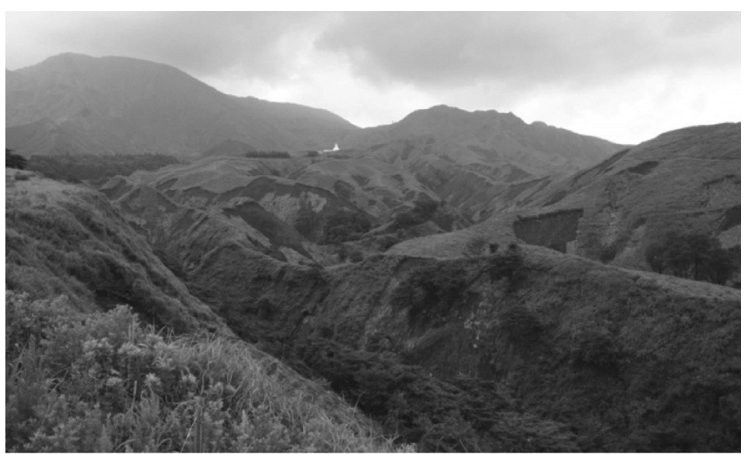

写真 -1 草地斜面の崩壊

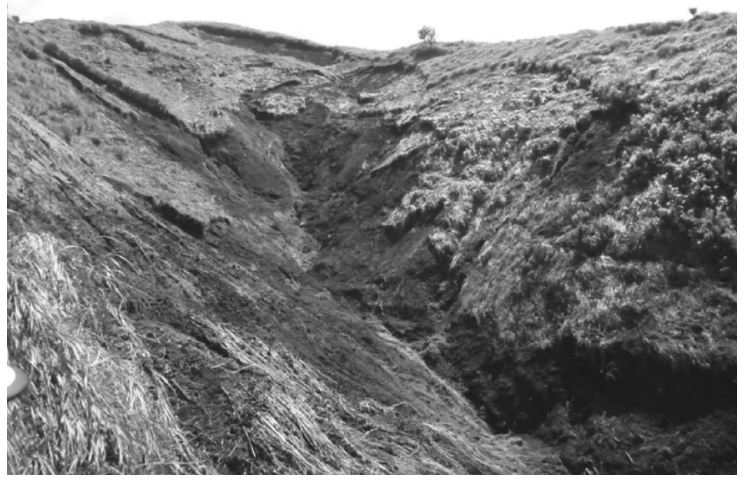

写真一 2 土砂の滑落跡 
流下した箇所では，被害が大きい（写真 - 4)。斜面の中腹には亀裂に富んだ溶 岩層が露出した箇所も多く, また山麓の 沢の出口は崖錐斜面となっている箇所も あった。このような箇所では，これらの 土石を巻き込むことにより被害が拡大し たことが考えられる。また，溶岩層上部 付近から多くの湧水が見られ, 地盤内部 で溶岩層が水文地質的境界の 1 つとなっ て崩壊の発生にも影響を及ぼしたと思わ れる。

\section{4. 外輪山の山麓部の地すべり}

外輪山の山麓斜面では崩壊性の地すべ りも見られた（写真 -5$)$ 。頭部滑落崖 において確認できる地層構造は，上位か ら黒色火山灰層, 黄褐色火山灰層, 碟混 じりの火砕堆積物層が累積しており，す ベり面は黄褐色火山灰層の中や下面付近 に見られた。また，黄褐色火山灰層と䃇 混じりの火砕流堆積物層の間に，シルト 質の火山灰層が見られる箇所もあり，そ のような部分ではこの火山灰層がすべり 面となった様である。崩壊土砂は黒色火 山灰の占める割合が多く, これらの土砂 は遠方にまで流れた箇所も見られた。

\section{5. 中央火口丘等の上部斜面の大規模な 崩壊}

根子岳や高岳の上部斜面の勾配が急な 場所では，表層崩壊が広い範囲で多数発 生した。また，大規模な崩壊の発生も見 られた (写真 -6$)$ 。遠景による観察の 限りではあるが，これらの中には崩壊面 積が大きく崩壊土量の大きいものも含ま れていると見られる。これらの大量の土 砂は渓流内にあった治山や砂防施設等に 被害を与えつつ，下流域に大きな土石流 被害を引き起こしたものと思われる。

\section{謝辞}

現地調査にあたり, 島根大学園山智和 氏，三谷康博氏，楊虎鋒氏にご協力いた だいた。また，林野庁および熊本県庁に
は現地調査にご配慮いただいた。記して 謝意を申し上げます。末筆ながら，甚大 な災害により被害に遭われた方々には謹 んでお悔やみを申し上げます。

\section{引用文献}

大丸裕武（2010）阿蘇地域の崩壊事例にみ られる森林の崩壊防止機能, 平成 22 年度 砂防学会研究発表会概要集, O 4-12.

清水晃, 竹下幸, 水谷完治（1992） 7.2 阿 蘇災害に打ける浅層崩壊について，日本 林学会九州支部研究論文集, No. 45,177 -178 .

宮縁育夫，大丸裕武，小松陽一（2004）2001 年 6 月 29 日豪雨によって阿蘇火山で発生 した斜面崩壊とラハールの特徵. 地形, 25 ( 1 ) , $23-43$.

（原稿受付2012年 8 月 22 日, 原稿受理 2012 年 9 月 4 日)

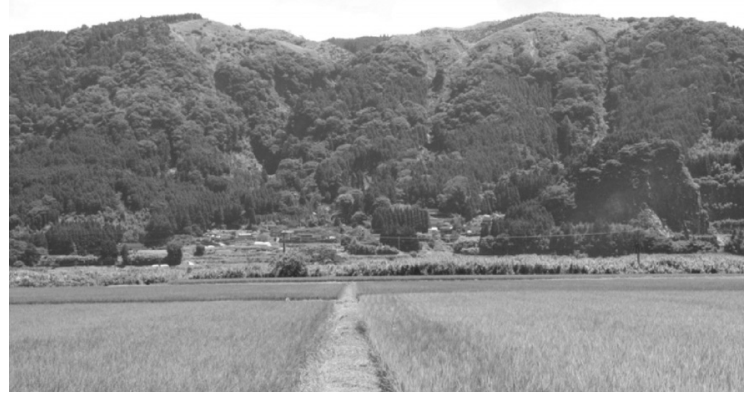

写真ー3 外輪山斜面で多数発生した崩壊や土石流

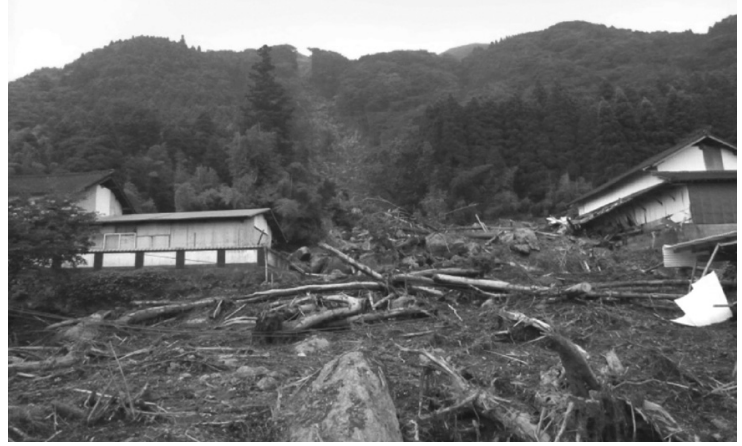

写真一 4 外輪山斜面の土石流の跡

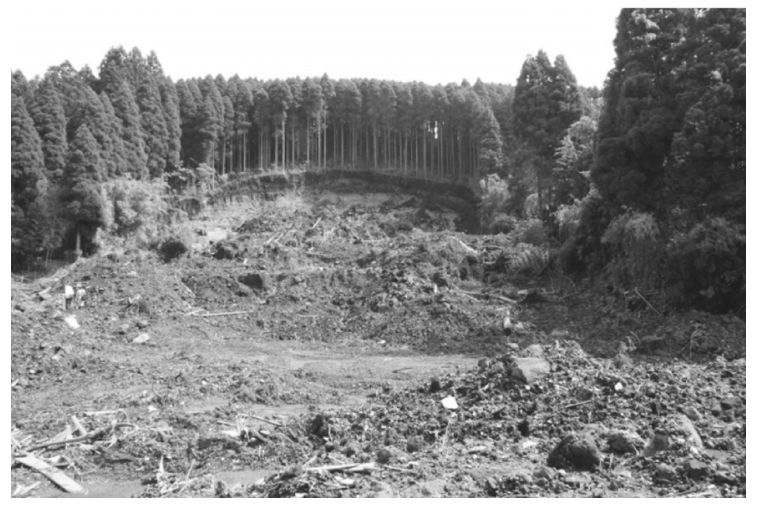

写真一 5 山麓斜面で起きた地すべり

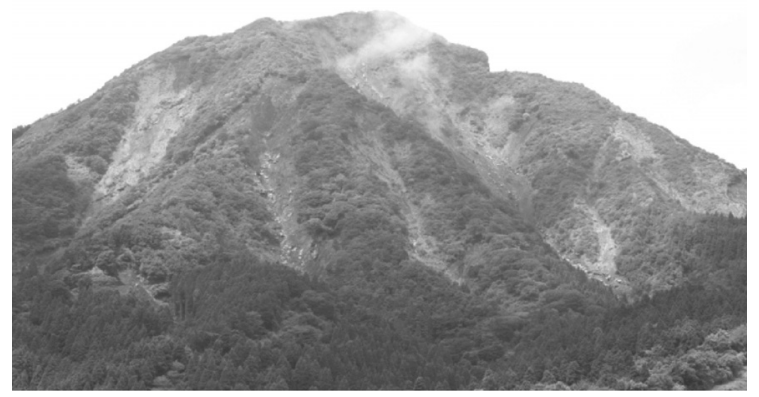

写真一 6 根子岳上部斜面で発生した大規模な崩壊

表 阿蘇地域の土砂災害調查グループ

\begin{tabular}{l|l}
\hline \hline \multicolumn{1}{c|}{ 浅野志穂 } & 森林総合研究所九州支所 \\
\hline 大丸裕武 & 森林総合研究所 \\
\hline 新井場公德 & 消防宁消防研究センター \\
\hline 福岡浩 & 京都大学防災研究所 \\
\hline 松四雄騎 & 京都大学防災研究所 \\
\hline 汪発武 & 島根大学総合理工学部 \\
\hline 齋藤仁 & 東京大学空間情報科学研究センター \\
\hline 古谷元 & 富山県立大学工学部 \\
\hline
\end{tabular}

